\title{
Māte Mahādēvi: a Progressive Female Mystic in Today's India
}

\author{
MARIE-THÉRÈSE CHARPENTIER \\ Åbo Akademi University
}

\begin{abstract}
Among the Indian female gurus active today, Māte Mahādēvi from the Lingāyat tradition in Karnataka (Southern India) is one of those attracting an increasing number of followers. Lingāyatism is a reform movement which according to certain views was founded by Basava in the twelfth century. The movement arose as a protest against the caste system, against a priesthood that was considered corrupt, and against discrimination against women. In the following paper, I provide a portrait of this religious revitalizer and mystic. I describe Māte Mahādēvi's background in the light of the Lingāyat tradition, discussed briefly here. I also provide an account of some of her central contributions to the renewal of Lingāyatism, and of the resistance her work has met with. In addition to providing a cogent introduction to a hitherto relatively unknown religious tradition, my purpose, through giving voice to Māte Mahādēvi's life and activities, is also to add to previous research by drawing attention to one of India's contemporary female spiritual masters, largely unknown to westerners.
\end{abstract}

Keywords: Lingāyatism, female spiritual leadership, revitalization, gender

A heated and still ongoing discussion has raged for several decades as to whether or not women have historically been religiously active. ${ }^{1}$ While Indian and western Indologists and historians of religion, as well as Christian

1 This article has been published in Swedish in Svensk religionshistorisk årsskrift 2001, vol. 10, edited by Svenska samfundet for religionshistorisk forskning, Uppsala 2002. The present article is a modified version of the Swedish one.

During the autumn of 1999 and January 2001, I had the privilege of being a guest at Māte Mahādēvi's āśram Basava Manțapa in Bangalore, Kūḍalasangama and Bijapur (Karnataka) for three weeks. My stays gave me the opportunity to conduct structured interviews and to engage in daily spontaneous talks. I want to express my sincere thanks to Māte Mahādēvi for her extreme hospitality and for giving me the opportunity to talk with her. I also want to thank Ursula King, professor at the University of Bristol (England) and Birgit Heller, professor at the Institut für Religionswissenschaft, Katholisch-Theologische Fakultät, Universität in Vienna (Austria) for their co-operation. 
missionaries from India's colonial period, assumed women's submissive, passive and practically insignificant role in society, postcolonial voices from both western and so-called 'Third World' feminists - have grown increasingly stronger. Their representatives claim that the stereotypical picture of the issue, grounded on the assumption of the general socio-cultural inferiority of women all over the world, distorts the overall picture, in that it is based on gross generalizations, allowing no room for exceptions. ${ }^{2} \mathrm{~A}$ number of monographs and in particular articles expressing the same spirit have been published, with the specific purpose of giving a less rigid picture of the situation. Such studies allow space for women's narratives of active participation in religious contexts, and depict women as active shapers and interpreters of their own history. ${ }^{3}$ Postcolonial feminists claim, amongst other things, that over the centuries a significant number of women played major religious roles. Many took an active role as spiritual masters or gurus, a function that from the beginning of time has been considered prestigious in India for both women and men. These roles have accordingly been regarded with an air of holiness and considerable respect. Nevertheless, it is not enough to note that these women existed: a number were actually honoured and celebrated by their followers during their lifetime (Lassell Hallstrom 1999). Today a significant number of women are active as gurus in various Hindu traditions, even if men remain the majority (White 1980; Clémentin Ojha 1990; McDaniel 1995; Narayanan 1999; Coney 1999; Charpentier 2010).

One of the female spiritual masters I met in southern India was the Lingāyat guru Māte Mahādēvi. ${ }^{4}$ With an educated and scholarly background, she is an unusual mixture of writer, mystic, poet, philosopher and religious activist, attracting an increasing number of followers. While Māte Mahādēvi

2 The debate which started within Christianity, Judaism and Islam has during the past two decades come to include Buddhism and Hinduism as well. Postcolonial feminists claim that the reason why such a notion was so widely accepted is that it contributed to justifying the presence of colonialists in India. See e.g. Kirin Narayan (1992, 70-2), or Veena T. Oldenburg (1994).

3 See e.g. Frédérique Apffel Marglin (1985), Julia Leslie (1992), Kathleen Erndl (1993) and Mandakranta Bose (2000).

4 The word lingāyat comes from the Sanskrit word linga, which according to Monier Monier Williams $(1993,901)$ means a mark, spot, sign, token, badge, emblem, characteristic and the possessive suffix yat. A lingāyat is therefore an owner/wearer of the linga. This has to do with istalinga ('chosen', 'own' linga) not with śivalinga. While the latter, as noted, appears phalluslike, the former looks like a round-shaped black stone with a flat bottom and symbolizes the Universe or faceless God. All Lingāyats wear the iștalinga around the neck; it is kept either in a purse or in a small silver box. During the daily meditation, which usually takes place alone, the linga is removed from its purse or box and is placed on the left palm to be looked at with half-open eyes. People do also $p \bar{u} j \bar{a}$ to the linga while it still rests in the hand, according to a rather complicated ritual employing petals, water, holy ash, sweets and rudrākșa. 
is briefly mentioned in studies by some scholars, e.g. Ursula King $(1984,80)$ and Jan Peter Schouten (1995, 229-30), to my knowledge no major study focusing on her has been published in English. One existing article is by the Austrian scholar Birgit Heller; this has been circulated amongst Māte Mahādēvi's āśram publications (Heller 1998a). It is based, among other things, on Māte Mahādēvi's own publications and on interviews with the guru, and focuses mainly on Lingāyatism's ideal of gender equality. It gives an exposition of Māte Mahādēvi's views, followed by Birgit Heller's critical perspectives and discussion of the guru's own religious movement in the context of the Indian Women's Movement (IWM). There is also Birgit Heller's monograph, Heilige Mutter und Gottesbraut: Frauenemanzipation im modernen Hinduismus (1999); this is a scholarly study dealing with women in the Rāmākṛṣna and Viśvadharma movements. Another academic article on Māte Mahādēvi by Birgit Heller has been published in German (1998b).

In the following pages, I provide a portrait of Māte Mahādēvi, giving an account of this unusual woman's life and personality, and examining her contribution to the rejuvenation of Lingāyatism. The portrait, which is largely descriptive, is mainly based on Māte Mahādēvi's own claims and beliefs. I further describe the resistance her provocative stance is frequently met with. While I am aware of the diversity of views related to Lingāyatism, my purpose here is to give voice to Māte Mahādēvi's interpretations of this religious tradition.

Māte Mahādēvi was born Rātnā on March 13, 1946 in Chitradurga (Karnataka) to a Lingāyat family of doctors from the Gāniga caste (oil makers) (Schouten 1995, 229). ${ }^{5}$ She had her first major spiritual experience when she was six years old, as her mother was reading to her about the different saints from the legends of the Epics and other religious texts. She became fascinated by the story of the purānas: about Dhruva, the devoted ascetic who met God in the forest. This awakened in Rātnā a longing to achieve enlightenment. As time went by, svāmī Vivēkānanda became a model for her. Along with her attraction to the spiritual life, Rātnā early showed a keen intellectual brightness. She was particularly skilled at literature and philosophy. She was later admitted to study Medicine, but was not allowed to commence her studies due to her relatives' objections. During her PreUniversity Course, her spiritual longing intensified. During this time she lived modestly, dedicating much of her time to meditation and the reading of religious books. During her final year of college she was told that the char-

5 Letter from Māte Mahādēvi, 27.6.2001. 
ismatic and well-known Lingāyat master, Lingānanda svāmī, was visiting her native town to deliver a lecture at a public religious gathering organized by the Taralabālu monastery of Sirigere. After some initial hesitation, she decided to participate; when, hours later, she was about to leave, she became aware that a fantastic transformation had taken place within her. ${ }^{6}$

Lingānanda svāmī later accepted her on this basis as a disciple, and she received her initiation, the so-called iștalinga dìkșa, on August $211965 .{ }^{7}$ Rātnā requested Lingānanda svāmī to give her the spiritual name Lalleśvarī after the female poet-saint from Kashmir, but instead Lingānanda svāmī named her Māte Mahādēvi, after Akkamahādēvi, the female poet-saint of Karnataka. ${ }^{8}$ He gave her his blessing and a photograph of Akkamahādēvi, whom he had worshipped for the last ten years. Afterwards, he declared: 'You are not an ordinary person. You have come to fulfil the will of those

6 Interview with Māte Mahādēvi in Bangalore on 18.11.1999.

7 Interview with Māte Mahādēvi in Bangalore on 18.11.1999. At the iștalinga initiation, the disciple receives an istaling $\bar{a}$ and the mantra Om lingaya namah and makes the vow to dissociate $\mathrm{him} /$ herself from meat and alcohol and to wear the iștalinga around the neck.

8 Akkamahādēvi is a southern Indian poet-saint from the twelfth century, known to have challenged her entourage through, among other things, under a short period of her life (when she was about eighteen years old), walking about naked, covered only in her long black hair. Akkamahādēvi grew up in an affluent family, and a young Jain king aspired to marry her. As he did not keep his promise of religious conversion, she left him and all her possessions, including her clothes. In one of her vacanas she writes as follows (translated by K. A. Ramanujan, in the collection of poems [1979, 131; poem number 184]):

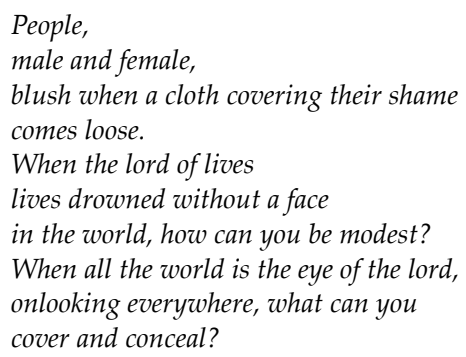

By giving up her body and all which binds her to the world, she wants to show that she is beyond all convention.

According to a talk I had with Māte Mahādēvi in Bangalore (Field notes 20.11.1999), nearly all the Indian poet-saints such as Mīrābāī, Lalleśvarī and Āṇ̣̂āl are worshiped as God as saguṇa ('with form'). She thinks therefore that Akkamahādēvi has gone a step longer when she gets one with God as nirguna ('without form'). Akkamahādēvi's early vacanas describe the first stage when she worships Śiva as Cenna Mallikārjuna ('Lord white as jasmine') while the later one describes the mystical union. Akkamahādēvi's biography is recorded in the text Śünyasampādane. 
śaranas of the twelfth century. ${ }^{9}$ You should be blessed by Akkamahādēvi. You are nothing but an incarnation of Akkamahādēvi.' ${ }^{10}$

Immediately after her initiation, Māte Mahādēvi decided to reside at Lingānanda svāmī's āśram (Viśva Kalyāṇa Maṇtapa) in Davangere, against the wishes of her relatives. However, Lingānanda encouraged her to have patience and advised her to continue performing tapasya ('austerities') at her parents' home. ${ }^{11}$

A central event with considerable bearing on Māte Mahādēvi's forthcoming spiritual calling occurred immediately after her istalinga initiation. One night, while sitting and meditating in front of the pictures of Siva and Akkamahādēvi in her home, she suddenly heard a laugh. The pictures came to life, and Māte Mahādēvi immediately asked Akkamahādēvi for her blessings: 'Sister, please bless me. Our guruji has told me to get your blessings and divine power.' Akkamahādēvi said: 'I am highly spiritual. Are you able to bear my spiritual energy?' whereupon Māte Mahādēvi answered: 'If I say I can bear, then it will be nothing but ego. I think it will be a hindrance to spiritual life but if you give me your power, I will be able to bear your spiritual energy.' Akkamahādēvi continued: 'I am satisfied with your answer. Please take me, I am ready to enter into you.' Māte Mahādēvi says that when Akkamahādēvi's light and energy came into her, she felt it as an explosion: her whole body began to shake. She then asked: 'Is there any proof that you have blessed me?' Akkamahādēvi concluded the conversation saying: 'From today onwards, you will have the capacity to sing and write.' ${ }^{12}$ The prophesy was fulfilled and from that day onwards, Māte Mahādēvi began to sing in spite of her previously poor singing-voice; moreover, a stream of literary creativity also engulfed her for the first time in her life. She immediately wrote (in the Kannada language) the collections of poems Māthru Vāni ('Mother's Voice'), Viraha Taranga ('The Waves of Separation') and Ganga Taranga ('The Waves of the Ganges'), published in 1966.

\footnotetext{
9 The word śarana means 'spiritual adept'.

10 Interview with Māte Mahādēvi in Bangalore on 18.11.1999. Observe that while Māte Mahādēvi is said to be an incarnation of Akkamahādēvi, she is not considered as an avatār, as Vaișnavism propounds, protecting good people and punishing evil ones. This is because Lingāyat followers do not believe in enlightened souls being reborn on earth, and thus do not accept the representation of a God in human guise. However they do believe that grace, God's blessings or great souls sometimes descend in some human beings. Letter from Māte Mahādēvi 27.6.2001.

11 Interview with Māte Mahādēvi in Bangalore on 18.11.1999.

12 Interview with Māte Mahādēvi in Bangalore on 18.11.1999.
} 
Two months after her initiation, Māte Mahādēvi moved to Viśva Kalyāṇa Manțapa in Davangere. On April 6 1966, when she was just twenty years old and scarcely eight months from the first initiation, she received samnyāsa dìkṣa, or rather jangama dìkșa as Lingāyats prefer to call it. By this means believers want to indicate that it is not a question of giving up the world and one's own responsibilities (samnnyāsa meaning 'to renounce') but is a clear attitude toward living in the world and 'adopting' the community as one's own family. Although at this time Māte Mahādēvi did not want to do anything else but spend her time immersed in deep meditation, Lingānanda svāmī advised her to continue her studies, because, he claimed, a life dedicated to introspection alone merely leads to spiritual selfishness. ${ }^{13}$

Meanwhile, Lingānanda svāmī and Māte Mahādēvi had to leave Davangere with some of their dedicated disciples because of the pressure they received from orthodox believers after giving shelter to a female spiritual aspirant. ${ }^{14}$ They settled down just outside Dharwar, where in 1968 they established a new āśram, the Jagañmātā Akkamahādēvi Āśrama (Schouten 1995, 229). According to Māte Mahādēvi, its purpose was to provide 'shelter, guidance and training for spiritual seekers, especially for girls and women who are dedicated to the propagation of religious values' (Mahadevi 1996, 4-5). After barely two years of study, Māte Mahādēvi obtained the Master Degree in Philosophy and Religion at Karnataka University. Years later, when she was about thirty years old, she was invited to become a research student at the University of London (UK) for one year, and then to complete her Ph.D. degree at Cambridge University. This occurred in 1976, after she had delivered a noteworthy lecture at the Symposium on Indian Religions in London, upon an invitation from The Institute of Oriental and African Studies of British Universities where she was a guest of honour. Nevertheless, feeling that her calling led elsewhere, Māte Mahādēvi did not take up the place. ${ }^{15}$

\section{Basava and the Rise of Lingāyatism}

In order to investigate Māte Mahādēvi's contribution to the rejuvenation of Lingāyatism, my purpose now is to consider the origins of this reform

13 Interview with Māte Mahādēvi in Bangalore on 18.11.1999.

14 In traditional Lingāyat mațhs, women were not allowed as spiritual aspirants.

15 Interview with Māte Mahādēvi in Bangalore on 18.11.1999. The conference took place in 1976 during an eight months stay in the UK. Māte Mahādēvi's lecture has been published in the booklet Lingayatism (Past and Present). 
movement. ${ }^{16}$ Although these are not quite clear, Lingāyatism, or Vīraśaivism as R. Blake Michael prefers to call it, includes two parallel traditions: that of the gurusthalins and that of the viraktas (Michael 1983, 310). The gurusthalins go back to five main teachers or pañ $\bar{a}$ āaryas, believed to be the founders of the religious tradition: Revaṇārādhya, Marulārādhya, Ekōrāmārādhya, Paṇditārādhya, and Viśvārādhya. These teachers established five monastic centres, at Bạ̣ehạ̣li (Karnataka), Ujjain (Karnataka), Śrīśaila, Kedāra, and Kāśî (Uttar Pradesh) respectively (Michael 1983, 312). The gurusthalins are 'ecclesial' in nature, and their organizations are said to be 'relatively formal and hierarchical' (Michael 1983, 318). The priests are hereditarily appointed, and ritual activity is complex and central to the tradition. Moreover, the ritual practice of the ācāryas shows continuity with established Brahmanic patterns.

In contrast to the gurusthalins, it is difficult to find clear formal structures within the virakta denomination, characterized by relative flexibility and the absence of hierarchy (Michael 1983, 316). The viraktas worship Basava as their spiritual master and value personal charisma rather than formal religious affiliation; inner spiritual experience is emphasized over outward religious practices. They break clearly with formal Brahmanic worldviews, and the ritual activities of the denomination are relatively 'simple and peripheral' (Michael 1983, 317). Moreover, while most gurusthalins do not engage in active proselytizing, such a function is important to viraktas (Michael 1983, 316-8). Due to a disregard of the co-existence of two parallel traditions, confusion and disputes have taken place not only among scholars but also among religious practitioners. ${ }^{17}$ One such example is quoted in J. P. Schouten's study, Revolution of the Mystics: Schouten notes that while working on his monograph, he was confronted with this 'cold war' when the senior guru of Ujjaini consistently refused to mention Basava's name in reply to his questions during an interview (Schouten 1995, 273).

While Māte Mahādēvi claims that she stands outside both the gurusthalin and virakta traditions, she nevertheless considers Basava to be the founder

16 Basavapurāna, a text from the thirteen century and Śūnyasampāanane, a fifteenth-century compilation of vacanas from different authors, are two central Lingāyat sources giving information about Basava's life and message, where historical evidence is mixed with literary and hagiographical accounts.

17 According to Birgit and Sten Rodhe, Marulāsiddha has a more prominent position than Basava among the present representatives of religious leadership in Sirigere (Rodhe 1997, 88). This is contradicted by André Padoux, according to whom, while Basava is named as the founder of Lingāyatism, Ēkāntada Rāmayya, a contemporary of Basava, appears as its main reformer (Padoux 1987, 12). In Dasgupta's study, Basava is nevertheless mentioned as a founder (Dasgupta 1955, 42). Schouten $(1995,2)$ and Ishwaran $(1992,2)$ agree with that claim. 
of Lingāyatism. ${ }^{18}$ Given that Basava is a significant source of inspiration for her, profoundly affecting her personality, her set of values, and the religious activism she engages in, it may therefore be pertinent to say something about his life and mission. Basava, also known as Basavanna (the suffix ann் meaning 'elder brother') or Basavēśvara ('Lord Basava'), as his followers preferred to call him, was born in the twelfth century in Bāgēvāḍi in north Karnataka to a brähmaña family (Schouten 1995, 2). ${ }^{19}$ His message is preserved in the so-called vacanas, consisting mainly of brief prose lyrics written in Kannada. ${ }^{20}$ This form of poetry dominated the literature of Karnataka in the middle ages and was used to propagate mass devotion. One specific feature of the vacanas is that they are easy to memorize. Along with Basava, noteworthy poets from the twelfth century include Cennabasava, Siddharāma, Allama Prabhu and Akkamahādēvi. In fact, more than two hundred other vacana-writers are said to have lived during this time (Schouten 1995, 10-11). ${ }^{21}$

According to the Basavapurāna, a text focusing on Basava's deeds, very early, perhaps already at the age of nine, Basava refused to undergo the upanayana ceremony where the sacred thread is given; he believed that religion should consist not of meaningless rituals and outward formalism but of

18 In an interview in Bangalore from 4.12.1999, Māte Mahādēvi criticises the gurusthalins as well as the viraktas vehemently. She criticises the viraktas for not living as they teach. According to her, while the viraktas theoretically do worship Basava, in practice they give prominence to their own gurus.

19 According to Schouten $(1995,2)$ and Ishwaran $(1992,60)$, Basava was born in 1105 CE, a fact that most researchers agree with. R. C. Hiremath, however, refers to $1131 \mathrm{CE}$, while Lingānanda svāmī and Māte Mahādēvi mention April 301134 CE as the date of birth (Hiremath 1967, 11; Mahadevi 1997, 5). The time of Basava's initiation similarly varies among different scholars. R. Blake Michael mentions that this occurred when Basava was twelve years old (Michael 1982, 206). In a letter from April 82000 in my possession, however, Māte Mahādēvi claims that only two dates concerning Basava's life can be accepted with certainty. She claims to have done research on the topic herself, and to have calculated a number of conversions from Gregorian to the Indian calendar. According to her, different writers incessantly repeat that Basava died 'on fifth day of Shravana month of Nalanama Samvatsara'. Converted to the Gregorian calendar, this is 30.7.1196. The date of Basava's arrival in Kalyāna, in 1160 ('Vikrama Nama Samvatsara'), according to Māte Mahādēvi, is also certain. In the vacanas it is said that he stayed in Kalyāna for about 36 years. His date of birth is more uncertain; but while the vacanas mention that Basava was 21 years old when he achieved enlightenment, she draws the conclusion that he was probably born in 1134 .

20 The word vacana comes from the Sanskrit root $v \bar{a} c$ ('talk', 'uttering').The term vacana can therefore be translated as 'uttering' or 'saying'.

21 Sadashiva Wodeyar says the following about the vacanas: 'They are in the language of the common man, simple, unsophisticated and elegant, but at the same time, embodying noble ideas and the highest truths of religion. The greatness of these vacanas is that they can touch the hearts and minds of even the humblest of men.' (Wodeyar 1967, X.) 
inner-longing (Michael 1983, 311). More fundamentally, he had an aversion towards the varna system which dominated the socio-cultural context of his time but which he experienced as hierarchical and inegalitarian (Schouten 1995, 2; Michael 1983, 311). ${ }^{22}$ According to Basava, it is not birth (i.e. being born within a 'superior' caste) that qualifies a human being to become a guru, but rather spiritual attainment; this in turn he believed to be based on personal skills, such as spiritual maturity, knowledge, dedication to spiritual practices, and morality. This implies that both men and women had the same opportunity to follow the path of asceticism (Schouten 1995). ${ }^{23}$ Accordingly, Basava turned away from Vedic authority, polytheism, image worship, rituals which had become complicated and an end in themselves, and which he believed were based on blind faith; he also rejected the temples and their priests, whose dissociation from true religiosity for the benefit of power and wealth involved animal sacrifice and discrimination against women.

This last point eventually led him to forbid child marriage and to encourage widows to remarry. Basava fought against the rituals which focussed on the so called 'five ritual impurities' (pañcasūtaka), which according to brāhmana orthodoxy were connected with delivery, menstruation, caste, saliva and death (Schouten 1995, 194). He believed that religion should be open to everyone, irrespective of caste or gender; instead of complex, superficial religiosity, he preferred moral purity and 'universal humanism, founded on harmonious human relations and social progress' (Ishwaran 1992, 45). Basava's aversion for Vedic authority is reflected in the following vacana:

If one sings the Gītā, so what?

If one hears the Śāstras and Purāṇas, so what?

If one reads the Veda and Vedānta, so what?

If one feels the highest experience, so what?

Unless he knows whole-hearted devotion to linga and jangama, so what?

None but the true devotee is fit

For our Lord of the Meeting Rivers. ${ }^{24}$

According to Māte Mahādēvi, while Basava was influenced by Buddhism due to its humanism and by Jainism on account of its non-violent principles, he ultimately rejected both: he judged that the first encouraged begging instead of working, while the second was governed by meaningless

22 Basavapurāna 3.44-96. According to Michael 1983, 311.

23 Interview with Māte Mahādēvi in Bangalore on 18.11.1999.

24 Quotation from R. Blake Michael's monograph 1992, 2. 
restrictions (Mahadevi 1997, 29). Basava's spiritual quest therefore induced him to leave Bāgēvāḍi for Kūḍalasangama, also called Kappaḍi, which lies at the confluence of the Kṛșna and Malaprabhā rivers (Michael 1983, 311). He joined a gurukula ('the house of the guru') giving religious training at a kālāmukha temple dedicated to Śiva (Schouten 1995, 2-3). There he was appointed as a priest and received a spiritual education, practicing yoga and studying ancient religious scriptures. While he did not become a devoted $k$ älämukha follower, the temple gave him the peace he needed to extend his own spiritual practice (Ishwaran 1992, 63). According to the legend, the question which unremittingly occupied his thoughts was: how can one worship a featureless God? Since boyhood, Basava had rejected the worship of idols. ${ }^{25}$ In answer to his question, he eventually had a vision of God in the form of Küdalasangamadēva, usually translated as 'The Lord of the Meeting Rivers'. He was advised to worship God as istalinga, and henceforth this became his sole guru (Mahadevi 1997, 43). ${ }^{26}$ After spending some twelve years at the gurukula, his spiritual identity became sufficiently strong that he was now ready to go his own way (Ishwaran 1992, 63). Basava married Nīlaganga (also called Gañgāmbike), the daughter of Kalyāna's prime minister Baladēva, on active service at the court, and was offered the post of treasurer at King Bijjalạ's court in Kalyāna (Schouten 1995, 3). Eventually, he established the Anubhāva Manțapa, or 'Hall of Spiritual Experience',

25 The term küdala in Kannaḍa means 'confluence' and is called sangama in Sanskrit.

26 Schouten believes that the iștalinga was in all probability introduced by Basava (Schouten 1995, 6). This view is echoed by Māte Mahādēvi in an interview in Bangalore on 18.11.1999. In Emblem of God, Lingānanda svāmī describes the linga as follows: 'Linga has no end, hence it has no beginning. For, whatever is born must meet with death; Linga, which has no beginning or end, is infinite. There is no space where Linga is not. For, Linga, or Śiva, is omnipresent and indwells everything.' (Lingānanda 1973, 32.) Further, he says: 'Linga is the highest Thing, the Absolute, the Paraśiva, the universal Soul [...]; Linga is the Energy, the immaculate, impartite, formless, peerless Principle without attributes, Linga is Existence-Consciousness-Bliss. Linga also is the soul' (Lingānanda 1973, 35). Through meditation on the istalinga, the devotee can participate in a mystical union. Lingānanda svāmī also refers to the experience of Allama Prabhu (one of Basava's disciples): 'To apprehend what is incomprehensible, to perceive what is imperceptible, is the mystic experience. It is not possible for the external eye to see the formless and tranquil Linga. However, by constantly gazing with unwinding eye the formless Linga manifest [sic] in the form of Iștalinga on one's palm, one can open one's inward eye. Visualising that invisible, formless Linga with the inward eye, Prabhu is thrilled with joy; and, like a child who has seen a dream, is astonished to experience the silent Brahman beyond words and pairs of opposites; [...].' (Lingānanda 1973, 33-4.) According to Lingānanda svāmī the linga is a necessary mean to get enlightened: 'To know the formless, form is necessary. Only through an emblem is it [sic] possible to gain the ultimate Consciousness.' (Lingānanda $1973,36$.$) This is sounded again in the following quotation: ' [\ldots]$ to adore the formless, one must adore the form' (Lingānanda 1973, 39). 
a meeting place for spiritual lectures and discussions; its aim was to offer spiritual training to the people, without distinction of caste, class or gender. Basava considered Anubhāva Manțapa as a 'spiritual laboratory', practicing the egalitarian ideals which he later hoped would apply to society in general (Schouten 1995, 4). As Anubhāva Manțapa's leader he established a śūnyapițha, a religious pontifical seat, where he installed Allama Prabhu, an ascetic from the śüdra caste (Schouten 1995, 4). The poet-saint Akkamahādēvi was among those who spent some time at Anubhāva Manțapa, after leaving her marital home (Schouten 1995, 168). Basava's achievements were sufficiently esteemed that he became prime minister; he made full use of his position to organize and strengthen the ties that existed between him and the growing score of devotees who shared his spiritual quest (Michael 1982, 207). As Māte Mahādēvi puts it, the town of Kalyāṇa became the centre for the so called 'spiritual revolution': 'the revolution started by Basavanna during the twelfth century brought a tremendous overall transformation in the spheres of social, religious, economic, political, moral, radical and was sharp enough to change the angle of perception of the people. [...] The revolution of Kalyana happened neither for women nor for wealth or land but to establish the equality of human beings by wiping out the discrimination of colour and classes.' (Mahadevi 1997, 96-7.)

Nevertheless, Basava's progressive ideas were not shared by the brāhmana orthodoxy and his followers were on a number of occasions persecuted. The fact he had installed Allama Prabhu, from the śüdra caste, as a religious leader and was himself a popular guru incurred many people's anger (Schouten 1995, 4). Moreover, Basava's ideas threatened the position and authority of the brähmana priests, who according to him made their living preying on people's blind faith. Repeated attempts were made on Basava's life, but he managed to escape (Schouten 1995, 4-5; Ishwaran 1992, 93). Nevertheless, a decisive event finally put an end to his success in Kalyāna. The prelude to this was the marriage that took place in 1167 between a brähmana girl and an untouchable, a ceremony which was encouraged by Basava as well as the followers of his religious community. The reaction was now so strong that King Bijjala gave in to pressure from the orthodoxy; Basava chose to resign his post as a prime minister and leave Kalyāna. As punishment for committing such a transgression, the bridegroom, the father and the father-in-law had their eyes plucked out and were condemned to death. King Bijjala was murdered the next year, and a period of political instability commenced. Before departing from Kalyāna, however, Basava passed on responsibility for the enduring survival of Lingāyatism to his followers, along with the 
palm leaves whereon the vacanas were inscribed. He died shortly thereafter. (Schouten 1995, 5.)

According to Māte Mahādēvi, while more than half of the texts were badly damaged, the remainder were saved and hidden in caverns. They were subsequently protected by the villagers of Karnataka, who worshipped them for centuries in their homes without actually knowing what they contained. ${ }^{27}$ It was not until the beginning of the twentieth century (1912-1914) that a man called Halakați went around the villages collecting the scripts; the first edition was published by him in 1934. (Ishwaran 1992, 19-20.)

\section{Some of Māte Mahādēvi's Most Important Contributions to the Revitali- zation and Rejuvenation of Lingāyatism}

Most scholars claim that Lingāyatism lost its impetus after Basava's death and remained weak, except from a few efforts to collect and compile the vacanas (Rodhe 1997, 86). According to Māte Mahādēvi, it was only in the middle of the twentieth century that the situation started changing, when Lingānanda svāmī decided to reform what he considered to be corrupted religion. This led in 1972 to the establishment of the Viśva Dharma Movement ('movement of universal religion') whose purpose was to instil 'great many changes into the religio-cultural milieu of India. This campaign initiated by Mataji [was] not a sectarian one with stereotyped ideas, but broadly based to show light to one and all without discrimination of caste, class and sex.' (Mahadevi 1996, 6.) The main reason for the spiritual decadence of the twelfth century, as already mentioned, was that it had become risky to practice Lingāyat religion as it threatened the priest-craft and temple-craft of Brahmanism. Unlike kālāmukhas, śaivas, vaișnavas and Jainism, Lingāyatism was not supported politically (Ishwaran 1992, 4). Moreover, Basava's followers were not prepared to resist the countermove of the orthodoxy. They had not yet had time to receive adequate training, since the Lingāyat movement was still in its initial phase. The religion was unstable, being neither systematised nor codified, and required more time to fully evolve. (Michael 1983, 312.)28

Māte Mahādēvi considers herself as one of the few present-day Lingāyat leaders who are firmly committed to revitalizing Lingāyatism: in other words, she wishes to purge Lingāyatism from several centuries' influence of Brahmanism. This has been achieved by returning to Basava's egalitar-

27 Interview with Māte Mahādēvi in Kūḍalasanggama (Karnataka) on 23.11.1999. According to Schouten, there are about ten thousands vacanas preserved (Schouten 1995, 11).

28 Interview with Māte Mahādēvi in Bangalore on 3.12.1999. 
ian ideals, as described in the vacana literature. One of her most important achievements has thus been to propagate Basava's message, working for its further recognition throughout the world. While Karnataka University published different editions of the vacana texts in 1968 and later, she claims that these were not widely read. ${ }^{29}$

Nowadays, Māte Mahādēvi is quite often found to be preaching, spreading the word, but more often than not this is ordinarily taken care of by other svāmīs from her religious community. Māte Mahādēvi spreads Basava's message mainly through the many articles and books she has written. She is particularly engaged in the task of collecting, analyzing, deciphering and interpreting the vacanas. The purpose of this is to clarify both their existence and content, and to foreground the religious elements of the texts. Nevertheless, Māte Mahādēvi considers that the vacanas are sometimes so ambiguous that it can be difficult for outsiders to understand that they do indeed convey an universal religious message. ${ }^{30}$ Māte Mahādēvi claims to have published over a hundred books, of varying length, and a considerable number of articles. These include collections of poetry, philosophical works, children's books, biographies, hagiographies, and more general works, in which she gives an account of her religious philosophy. Some of her works have been translated into English.

In 1967, at the age of twenty one, Māte Mahādēvi published Basava Tattva Dārśan, a study of 824 pages describing Basava's philosophy. According to her, the book was considered to be of such significance that the teachers at Karnataka University, where she was then a Master's student, made it obligatory reading for other graduate students. ${ }^{31}$

Māte Mahādēvi believes that one of her first and foremost contributions to the rejuvenation and reestablishment of Lingāyatism was to clarify the difference she posits between Lingāyatism and Vīraśaivism. According to her, these two concepts were over the years placed on an equal footing and have been problematic for most scholars. R. Blake Michael argues that the term 'Vīraśaivism' refers to a philosophical and theological system as well as to a historical, social and religious tradition, while the term 'Lingāyatism' is aimed at a modern social group that follows the Vìraśaiva tradition (Michael

29 Interview with Māte Mahādēvi in Bangalore on 3.12.1999.

30 Interview with Māte Mahādēvi in Bangalore on 3.12.1999.

31 Interview with Māte Mahādēvi in Bangalore on 3.12.1999. The following books have been published in English: A Guide to Lingayatism, Dharwar 1973; Lingayatism (Past and Present), Bangalore 1986 (1977); Who is a Hindu?, Bangalore 1989; Lord Basava - The Light of the World, Bangalore 1990; and Sri Basaveswara: Beacon of the Universe. 
1992, 18). ${ }^{32}$ Māte Mahādēvi, in contrast, claims resolutely that Lingāyatism differs completely from Vīraśaivism both philosophically and culturally. In the booklet Lingayatism (Past and Present) she writes: 'Lingayatism, a South Indian religion is not very well known owing to its literature being mostly in Kannada. Though it has been referred to by many scholars such as Mr. Benjamin Walker, in Hindu World, Ninian Smart in A Dictionary of comparative religion and Surendranath Dasgupta in History of Indian Philosophy the information provided is very scanty; and sometimes quite contrary to the original sources.' (Mahadevi 1986, 1.)

Māte Mahādēvi has travelled around southern India investigating this issue and claims to have come to the following conclusion: Vīraśaivism - found almost exclusively in some parts of Tamil Nadu (Chidambaram, Mylam, Pondicherry, etc) - Kerala and Andhra Pradesh represents the seven śaiva cults already in existence before Basava's time (Mahadevi 1986, 7-8). ${ }^{33}$ Its followers support the fourfold caste system, and some of the viraśaivas designate themselves as brāhmana-vīraśaivas, vaiśya-vīraśaivas, etc. ${ }^{34}$ Moreover, Vīraśaivism is based on śaiva-texts, such as the virraśaivāgama and the vìraśaivagurupāramparā (Dasgupta 2000, 46). Its followers worship Śiva in temples as sthāvaralinga (static linga); the linga they wear around the neck has a śivalinga appearance. ${ }^{35}$ In contrast, she claims that Lingāyatism is based entirely on the vacana texts of Basava and his contemporaries and rejects the notion of caste; its followers do not worship Śiva as sthāvaralinga or portable sivalinga but God in the form of iștalinga. ${ }^{36}$

Another of Māte Mahādēvi's contributions is the creation of a female jagadguru pițha (jagadguru means 'world-guru' and pittha 'seat'), which took the name Jagañmātā Akkamahādēvi Anubhāva Pìtha. The Jagadguru position, which exists in both the Śankarācarya and the Lingāyat tradition, is said to be reserved for exceptionally spiritually developed people and has hitherto merely been reserved for men. The initiative was taken in December 1968,

32 Footnote 1.

33 In a letter from Bangalore dated 8.4.2000, Māte Mahādēvi mentions the following sects: kālāmukhas, kāpālikas, adiśaivas śuddhaśaivas, pūrnaśaivas, vīraśaivas and pāśupatas.

34 Interview with Māte Mahādēvi in Bangalore on 4.12.1999.

35 As already mentioned, Śiva linga has a phallus-like appearance.

36 In Lingayatism (Past and Present), Māte Mahādēvi writes as follows: 'Virasaivism allows the worship of Sivalingam as the symbol of Siva, a deity among the Hindu trinity, whereas Lingayatism does not encourage the worship of Brahma, Visnu or Siva. Though the Lingayat literature is more sympathetic towards Siva than Visnu or Brahma, it firmly supports the monotheistic worship of "Istalinga" as the symbol of Absolute Reality, denominated in the metaphysics of Lingayatism as Para-Siva.' (Mahadevi 1986, 7.) 
when Māte Mahādēvi was twenty-two years old, at an 800-year anniversary celebration arranged by the Government of Karnataka to commemorate Basava's birth. The celebrations included a series of public lectures, and one day, while delivering a lecture, Māte Mahādēvi received what she calls 'divine inspiration'. She suddenly declared, without forethought: 'To fulfil Basava's ambition, I would like to establish a woman Jagadguru Pìtha', an initiative that Lingānanda svāmī strongly welcomed. ${ }^{37}$

According to Schouten, if we go back to Basava's life in the twelfth century, the vacanas show that both female and male followers enjoyed equality of every kind; many female ascetics were particularly influential (Schouten 1995, 157). Basava evidently considered Akkamahādēvi as a guru in her own right, with a competence and authority equal to male spiritual masters, even if this occurred after a certain trial period. In Mahamane, a house established by Basava for religious experiments, there were about sixty female saints, twenty of who composed vacanas. In addition, something occurred that Schouten considers more noteworthy: many of the followers and saints were married women. Though they lived in conventional marriages, they tried to devote themselves to the mystical life, aiming at achieving enlightenment - something considered extremely unusual in the Hindu tradition of that time. (Schouten 1995, 174-5.)

Women from traditionally uneducated circles contributed to the changing nature of society; many of them composed vacanas, delivered lectures and participated in discussions at religious gatherings (Schouten 1995, 197). Even prostitutes were accepted as members of the new spiritual movement (Schouten 1995, 181). This had positive social consequences for Lingāyatism's members, a fact which is reflected in Māte Mahādēvi's booklet Lingayatism (Past and Present):

Widows are in no way considered as bad-omens, an idea which is strongly prevalent in many other communities. As a widower is allowed to undergo successive marriage, a widow is allowed as well to undergo remarriage. After the death of her husband a Lingayat widow is not supposed to remove any ornament except the wedding locket. And she is not expected to shave her head. Shaving of a widow's head and 'Sati' - the custom of burning her alive with her deceased husband were abolished from society, long ago by the great social reformer Basava. (Mahadevi 1986, 30.)

37 Interview with Māte Mahādēvi in Bangalore on 18.11.1999. 
Nevertheless, as Schouten puts it, during the centuries that followed, Lingāyat-women successively lost their prominent position because, as noted, of the conservative forces which increasingly began to control the socio-cultural context of Karnataka. ${ }^{38}$ On April 211970 Māte Mahādēvi became the first female jagadguru, despite violent protests from various svāmīs of another Lingāyat community. The ceremony was conducted by Mallikārjuna svāmī from Śivānanda mațha in Gadag. (Schouten 1995, 229.) (9) $^{39}$ Citing herself as an example, Māte Mahādēvi declared that women had the same potential capacity as men to reach this honour.

In 1992, Lingānanda svāmī and Māte Mahādēvi went on to establish a mahājagadguru pịtha (not merely jagadguru pịtha, i.e. 'world-guru seat', but 'great [mahā] world-guru seat'). Lingānanda svāmī became the first mahājagadguru in 1992, and after his death Māte Mahādēvi succeeded him in 1996. This initiative, according to Māte Mahādēvi, came as a reaction to a long period of religious decadence. She claims that during Basava's time strict monotheism prevailed among Lingāyat followers and God was worshiped as iștalinga, i.e. as a faceless entity. After Basava's death, the Lingāyat followers began to withdraw from this ideal and worshiped a large number of local gods. Simultaneously, individual cults came into existence centred on different Lingāyat-svāmīs who established mațhas. After their death, their samādhis ('graves') became objects of worship; this explains the fact that even today there are still many of these samädhis. As a result, people forgot that Basava was the founder of Lingāyatism and the primordial guru and prophet who first received God's message. The idea of a mahäjagadguru pițha is thus to promote a representative of Basava's monotheism, thereby breaking the local cults. According to Māte Mahādēvi, this piț ha is equivalent to the official position held by the Catholic Pope. ${ }^{40}$

Māte Mahādēvi considers it very important to find different equivalents to well-established world religious terminology and distinctive institutional features, in order for Lingayyatism to be respected and its authority to increase. She is therefore working intensely to make it one of the familiar world religions. Currently she is writing something she calls Dharma Grantha, a holy book in Kannada, which she hopes will function as a text occupying

38 More information can found in Jan Peter Schouten's doctoral thesis, in the compilation in the chapter titled 'Position of Women' (Schouten 1995, 143-242).

39 According to Māte Mahādēvi, the term jagadguru corresponds to what westerners call 'bishop' in the Christian tradition. There is a difference between guru and jagadguru (worldguru), where the later is considered to have higher status than the former.

40 Interview with Māte Mahādēvi in Bangalore on 18.11.1999. 
the same position as the Christian Bible, the Muslim Koran or the Sikhs' $\bar{A} d i$ Granth. Māte Mahādēvi's purpose is to give believers practical, moral, and spiritual guidance. According to Māte Mahādēvi, while there are texts such as Śñnyasampādane, in which the vacanas were collected according to certain philosophical concepts, they do not contain the rites, customs, and rituals that people need. Her hope is thus that the new book will function as a guide not only for the Lingāyat community but for all humankind. ${ }^{41}$

To my question whether Lingāyatism is a separate religion, Māte Mahādēvi answered, 'Yes'. When I further asked whether Lingāyatism is completely separate from Hinduism, she answered that it depends on how we define Hinduism. If we put Hinduism on an equal footing with Brahmanism, it is evident that Lingāyatism does not belong to Hinduism; but if we apply a broader definition, involving other Indian religions such as Buddhism, Jainism and Sikhism, this may also include Lingāyatism. ${ }^{42}$

Along with her now deceased guru Lingānanda svāmī, Māte Mahādēvi is the initiator of the Śaranamēla, a large annual religious gathering taking place in Küdalasangama over four days at the beginning of January. ${ }^{43}$ In 1987 land was purchased for the establishment of Basava Dharma Pittha, very close to the temple where Basava achieved enlightenment and was buried, and a Lingāyat temple, a main building and a guest-house were constructed. An extension with additional buildings is planned for the near future. The first Śaranamēla took place in January 1988, after which the two gurus came to believe a gathering place was needed for Lingāyat followers residing in different parts not only of India but in the rest of the world as well. This Śaranamēla receives a large number of visitors, even if an exact figure is difficult to state. (Schouten 1995, 230.) ${ }^{44}$ One goal of the Śaranamēla is to strengthen the followers' religious identities. ${ }^{45}$ Due to Māte Mahādēvi's strenuous efforts to spread Basava's message, giving him the recognition she thinks he deserves, the politicians from the province of Kar-

41 Interview with Māte Mahādēvi in Bangalore on 3.12.1999.

42 See also Māte Mahādēvi's book Who is a Hindu? where, among other things, she gives the following definition of Hinduism: 'Hinduism is a word signifying a mass of people of common culture. It is a confederation of many religions - there are many religions and cults in this federation. Saivism, Vedic Religion, Buddhism, Jainism, Lingayatism and Sikhism are the important religions that come within the "Solar System" of Hinduism.' (Mahadevi 1989, 96.) According to R. Blake Michael, the answer to the issue is 'far from unanimous' (Michael 1992,9). 43 Lingānanda svāmī died 1996.

44 When I was in Küdalasangama in January 2001, it was said that between 100000 and 150000 people attended the Śaraṇamēla every day (field-notes, 15.1.2001). The number of participants is questioned by Schouten (Schouten 1995, 230, footnote 205).

45 Interview with Māte Mahādēvi in Bangalore on 3.12.1999. 
nataka have begun to develop its tourist industry around the temple where Basava was enlightened. Hotels, restaurants, a research centre, a library etc. are flourishing. A stamp has even been issued by the Government of India on Māte Mahādēvi's initiative, commemorating the 800th anniversary of Basava's death.

What distinguishes Māte Mahādēvi is her way of communicating and mixing with ordinary people, making her very accessible. This distinguishes her quite clearly from most of the gurus I have met. When she is not away from home preaching or blessing people, she stays at her residence (mutt or 'monastery') working in part on one or several of her forthcoming books and partly taking care of paperwork and administration. However, this does not prevent people who, for whatever reason, need to meet her going whenever they want up to her room to talk with her. This not only applies to craftsmen, architects, lawyers, etc, who help her with her activities but anyone in need of psychological or spiritual guidance, devoted followers and the unenlightened.

Unlike many other gurus, Māte Mahādēvi claims not being interested in opening schools, colleges or hospitals. As noted, her calling lies in another direction. She claims that one reason for this is that to do so presupposes co-operation with the authorities which limits one's freedom. Moreover, she does not recognize well-known politicians among her followers. Māte Mahādēvi also refuses to accept economic support from the state since she runs the risk of being in a state of dependence which may force her to compromise her ideals. Her activities are thus driven exclusively by donations offered by her followers. She claims that the only driving force for her mission is to purify not only Lingayyatism, but the Indian society in general from all present corruption by spreading Basava's egalitarian vision of society. ${ }^{46}$

\section{A Dangerous Business}

Māte Mahādēvi's popularity is said to be on the increase nowadays because of her intellectual ability and qualities as a charismatic and engaging speaker. Accordingly, she naturally draws a continuously increasing number of followers. However, just as Basava met immense resistance, Māte Mahādēvi's progressive ideas and her popularity have awakened anger and jealousy from other jagadgurus and svāmins. A number of incidents have consequently occurred over the years: here I describe some of them. Nota bene: while these

46 Talk with Allama Prabhu svāmī at Basava Maṇțapa in Bangalore on 25.11.1999. 
accounts have been told to me by Māte Mahādēvi, I have not been able to collect other people's testimony on the issue. Māte Mahādēvi told me, for example, that the first Śaranamēla incurred bad blood from many svāmīs, as they did not want to have such a public gathering. They therefore hired people with cases full of snakes and scorpions to frighten the gathered followers away. ${ }^{47}$ Another serious incident relating to Māte Mahādēvi's radical position as a religious leader, which almost cost her life as well as the lives of her followers, occurred in 1997. It started when, in a book published 19 August 1996, Māte Mahādēvi referred to God using both the names Küdalasangamadēva and Lingādēva. This decision was made after close examination of Basava's texts, where Māte Mahādēvi observed that Basava had used the first term as his pen-name before he was enlightened, the later after achieving enlightenment. ${ }^{48}$ Since the first name had been the only one accepted ever since the twelfth century, Lingāyat-svāmīs from other communities were furious and a few of them began to plot the assassination of Māte Mahādēvi and her followers. The place and time for the murder were decided: it was to take place at the annual Śaranamēla, where people from all over India would be gathered. On January 12 1997, seventeen people were arrested for illegal possession of weapons while they were driving to Küdalasangama. The police were tipped off about the planned attack. Another group, who had already arrived for the gathering, aroused the suspicion of many people there who recognized them as hired criminals. They too were arrested, having been bribed to poison the food and drinking water at the Śaranamèla. One final group had been given the task of burning down the huge pandāl (tent) erected as a meeting place for religious functions, along with the people gathered there. However, while the attackers were driving in two cars to carry out the crime, one of the cars collided with a transport bus at a crossroads and burst into flames. Six of the seven men died immediately and the seventh was severely injured, while the crew of the other car fled. The victims' relatives were offered large amounts of money by the svāmins to keep quiet about the circumstances of the accident. When I asked if the svāmīs were imprisoned for this, Māte Mahādēvi said that this could never happen in India; these men are wealthy and politically

47 Interview with Māte Mahādēvi in Bangalore on 3.12.1999.

48 In an interview with Māte Mahādēvi in Bangalore on 3.12.1999, Māte Mahādēvi called this initiative 'the crown of all my achievements'. Even though the initiative was taken as early as 1996, it is still subject to much controversy among other religious leaders. See for example: 'Mathe Mahadevi comments draw flak,' The Hindu. Online Edition of India's National Newspaper, Tuesday, Mars 26, 2002. 
too powerful. While they do not hold any formal political position in society, they are still able to corrupt the police system and thus benefit from its help and protection. The incident was serious enough to put an end to the perpetrators' plans, and gave rise to such a wave of publicity that no other serious events have occurred since. ${ }^{49}$

While Māte Mahādēvi's life is for the present not threatened, she still meets with a good deal of resistance. Currently she is in contact with a lawyer with regard to an incident which occurred in the city of Chitradurga several years ago. Some of Mātājì's followers had collected money to build Basava Manțapa, a Lingāyat prayer hall, a decision which was regarded with considerable disapproval by Murugharajendra svāmī, a monk from another monastery. He decided to put an end to her socio-religious activities in the city, engaging criminals as accomplices. On June 2 1996, while people were gathered for prayers, the police came and arrested all the participants after receiving a complaint that unknown people had 'occupied' the prayer hall. Innocent villagers, women, children, old people and students were wrongfully arrested and the prayer hall closed. Māte Mahādēvi managed to get the forty four participants released, but five years later the case had not been resolved even though it had been brought to trial a number of times. The prayer hall, which remained in Murugharajendra svāmī's charge, was at the time rented out for various functions..$^{50}$

Māte Mahādēvi takes all these efforts to stop her religious activities with serenity. She claims that she continuously receives guidance and support from God in the form of dreams, visions, and what she herself calls 'intuitive inspiration' ${ }^{51}$ She is convinced that she is protected by Basava and Akkamahādēvi, since she has observed that all attempts to injure or kill her or her followers have ultimately turned to her advantage. Commenting on the second incident described above, she says:

We have surrendered to the feet of God, so God is planning something good for me because he has never placed me in any trouble. Though it seems to be trouble, once again, it will be changed into something good. I think God is great justice so he should show good results. [...] They wanted to make me a great sinner by changing the name from Kūdalasangamadēva to Lingādēva but now, within three years, it has given me very good fame among the devotees. And when they took foul steps to burn our pandāl, it

49 Interview with Māte Mahādēvi in Bangalore on 3.12.1999.

50 Interview with Māte Mahādēvi in Bangalore on 3.12.1999.

51 Interview with Māte Mahādēvi in Bangalore on 18.11.1999. 
was exposed to the whole world and people lost faith in those svāmīs. They wanted to blacken my name but their names were blackened instead and my fame and support from people increased. ${ }^{52}$

Māte Mahādēvi claims that

[s]cholars have categorised the various roles of Basava as those of a prophet and path-finder, savant and seer, religious leader and social reformer, rebel and free thinker, mystic and man of action, liberator of the downtrodden and emancipator of women, liquidator of untouchability, harbinger of equality, messenger of the dignity of labour and the messiah of the masses, herald of a new literary renaissance and a leader of a great people's movement [...] (Mahadevi 1986, 5-6).

Referring to Akkamahādēvi, Birgit Heller reiterates the following expressions which have previously been used to describe her: 'radical mystic', 'intellectual par excellence', 'philosophical giant' (Heller 1998a, 78). Similarly, Māte Mahādēvi stands out, as noted here, as a colourful and controversial personality with many skills: she is a scholar and a religious revitalizer, as well as a writer, poet, philosopher, speaker, preacher, mystic and administrator. She also stands as a free thinker, with a loathing for corruption, and as one who with courage, engagement, warmth, purposefulness, empathy and intellectual brilliance strives to be faithful to Basava's egalitarian vision of society despite the resistance her work has met with.

The discussion regarding women's religious roles throughout history has seemingly just begun: it will clearly take time before the pieces of the complex Hindu mosaic fall into place and our understanding of events can be fully formulated. The fact that women were active in religious debates rather than passive victims appears more and more evident nowadays, even if we do not know to what extent, or in which federal state, caste or century, things actually occurred. For the time being we must be content to establish and celebrate the fact that women were found in leading religious positions, just as they are today. While Māte Mahādēvi's life and achievements are representative solely of her own religious tradition, she shares her prestigious role with many other female gurus. As in Māte Mahādēvi's case, these women are strong, independent, unconventional, charismatic figures with an unusual degree of integrity. Many have numerous follow-

52 Interview with Māte Mahādēvi in Bangalore on 3.12.1999. 
ers, both male and female, and have an excellent reputation; one that for some of them is steadily growing and at an international level. The fact that these female spiritual masters have until now led a relatively invisible existence compared to contemporary male gurus seems noteworthy; in the final analysis, however, it serves as a worthy comment on the ongoing gender power struggle that still prevails.

Bibliography

Primary Sources

Heller, Birgit

1998a Vision of Equality: Women in Lingāyatism. - Basava Sourabha: A Souvenir, All India, Seventh Basava Dharma Conference of Mumbai, 10-12th of October 1998, 70-84. Bangalore: Lotus Printers.

Hiremath, R. C.

1967 Śrī Basavēśvara: A Biography. - Śri Basaveeśvara, Eighth Centenary Commemoration Volume, Government of Mysore, 3-30. Mysore: Manipal Power Press.

\section{Lingananda, Swami}

1973 Emblem of God. Dharwar: Jaganmata Akkamahadevi Ashrama.

\section{Mahādēvi, Māte}

1973 A Guide to Lingayatism. Dharwar: Jaganmata Akkamahadevi Ashrama. 1986 Lingayatism (Past and Present). Bangalore: Viswakalyana Mission.

1989 Who is a Hindu? Bangalore: Viswakalyana Mission.

1990 Lord Basava - The Light of the World. Bangalore: Viswakalyana Mission.

1996 Her Holiness Sriman Niranjana Mahājagadguru Māte Mahādēvi: a Profile. Bangalore: Viswakalyana Mission.

1997 Sri Basaveswara: Beacon of the Universe. Bangalore: Viswakalyana Mission.

Wodeyar, Sadashiva

1967 Introduction. - Śrī Basaveeśvara. Eighth Centenary Commemoration Volume. Government of Mysore, IX-XII. Mysore: Manipal Power Press.

\section{Secondary Sources}

Bose, Mandakranta (ed.)

2000 Faces of the Feminine in Ancient, Medieval, and Modern India. New York: Oxford University Press. 


\section{Charpentier, Marie-Thérèse}

2002 Mate Mahadevi: en progressiv kvinnlig mystiker i dagens Indien. - Svensk religionshistorisk årsskrift 2001:10, Svenska samfundet för religionshistorisk forskning, 9-33. Uppsala: Swedish Science Press.

2010 Indian Female Gurus in Contemporary Hinduism: A Study of Central Aspects and Expressions of their Religious Leadership. Åbo: Åbo Akademi University Press.

\section{Clémentin Ojha, Catherine}

1990 La Divinité Conquise: Carrière d'une Sainte. Nanterre: Université de Paris V.

\section{Coney, Judith}

1999 Sahaja Yoga: Socializing Processes in a South Asian New Religious Movement. New Delhi: Oxford University Press.

\section{Dasgupta, Surendranath}

2000 A History of Indian Philosophy 5 (Vol. 5). Delhi: Motilal Barnasidass Publishers.

\section{Erndl, Kathleen M.}

1993 Victory to the Mother: the Hindu Goddess of Northwest India in Myth, Ritual and Symbol. New York: Oxford University Press.

\section{Heller, Birgit}

1998b Her Holiness Mahājagadguru Māte Mahādēvi: Weibliche Leitung als Ausdruck der Gleichberechtigung bei den Lingāyats. - Manfred Hutter (ed.), Frau und Göttin: Die Rolle des Weiblichen in der Indischen und Buddhistischen Kulturgeschichte, 75-85. Graz: Arbeiten aus der Abteilung 'Vergleichende Sprachwissenchaft'.

1999 Heilige Mutter und Gottesbraut: Frauenemanzipation im modernen Hinduismus, Wien: Milena Verlag.

\section{Ishwaran, K.}

1992 Speaking of Basava: Lingayat Religion and Culture in South Asia. Boulder: Westview Press.

\section{King, Ursula}

1984 The Effect of Social Change on Religious Self-Understanding: Women Ascetics in Modern Hinduism. - Kenneth Ballhatchet \& David Taylor (eds), Changing South India: Religion and Society, 69-83. London: Curzon Press.

\section{Lassell Hallstrom, Lisa}

1999 Mother of Bliss: Ānandamaȳ Mā (1896-1982). Delhi: Oxford University Press. 


\section{Leslie, Julia}

1992 Roles and Rituals for Hindu Women. Delhi: Motilal Barnasidass Publishers.

\section{Apffel Marglin, Frédérique}

1985 Wives of the God-King: the Rituals of the Devadasis of Puri. Delhi: Oxford University Press.

McDaniel, June

1995 A Holy Woman of Calcutta. - Donald S. Lopez Jr. (ed.), Religions of India in Practice, 418-25. Princeton: Princeton University Press.

\section{Michael, R. Blake}

1982 'Linga' as Lord Supreme in the Vacana-s of Basava. - Numen: International Review for the History of Religions, 24 (2), 202-19.

1983 Foundation Myths of the Two Denominations of Vīraśaivism: Viraktas and Gurusthalins. - The Journal of Asian Studies (JAS), 17 (2), 309-22.

1992 The Origins of Vìraśaiva Sects: A Typological Analysis of Ritual and Associational Patterns in the Śunyasampādane. Delhi: Motilal Barnasidass Publishers.

\section{Monier Williams, Monier}

1993 A Sanskrit-English Dictionary. Delhi: Motilal Barnasidass Publishers.

\section{Narayan, Kirin}

1992 Storytellers, Saints, and Scoundrels: Folk Narrative in Hindu Religious Teaching. Delhi: Motilal Barnasidass Publishers.

\section{Narayanan, Vasudha}

1999 Brimming with Bhakti, Embodiments of Shakti: Devotees, Deities, Performers, Reformers, and Other Women of Power in the Hindu Tradition. - Arvind Sharma \& Katherine K. Young (eds), Feminism in World Religions, 25-77. Albany: State University of New York Press.

\section{Oldenburg, Veena T.}

1994 Elisabeth Bumiller, May You Be the Mother of a Hundred Sons: A Journey among the Women of India [book review]. - Manushi: a Journal of Women and Society 84, 39-43.

\section{Padoux, André}

1987 Vīraśaivas. - Mircea Eliade (ed.), The Encyclopedia of Religion 13 (16), 12-13. New York: New York: Macmillan Publishing Company.

Ramanujan, A. K.

1979 Speaking of Siva: Translated with an introduction by A. K. Ramanujan. Chicago: Penguin Books. 


\section{Rodhe, Birgit \& Sten Rodhe}

1997 The Lingayats of Karnataka: an Introduction. - Lennart Svensson (ed.), Meeting Rivers: A Report on Transnational Cultural Flows and National Cultural Processes, 79-105. Lund: Lund University Press.

\section{Schouten, Jan Peter}

1995 Revolution of the Mystics: on the Social Aspects of Virraśaivism. Delhi: Motilal Barnasidass Publishers.

\section{White, Charles S. J.}

1980 Mother Guru: Jnanananda of Madras, India. - Nancy Falk \& Rita Gross (eds), Unspoken Worlds, Women's Lives in Non-Western Cultures, 15-24. Belmont: Wadsworth Publishing Company.

\section{Other Sources}

Interviews with Māte Mahādēvi taking place in Bangalore 18.11.1999, 3.12.1999 and 4.12.1999

Field notes, 18.11.1999-3.12. 1999 and 14.1.2001-16.1.2001

Letter from Māte Mahādēvi, 8.4.2000

Letter from Māte Mahādēvi, 27.6.2001

'Mathe Mahadevi comments draw flak', The Hindu. Online Edition of India's National Newspaper, Tuesday, Mars 26, 2002. http://www.hinduonnet. com/2002/03/26/stories/2002032601150500.htm <accessed 10.2.2011> 


\section{Appendix: Figures}

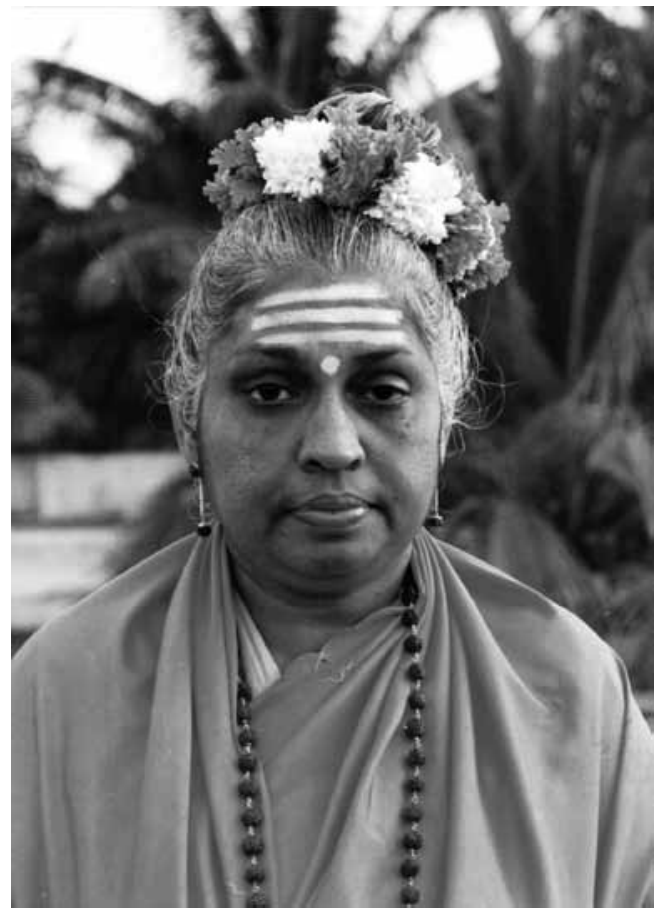

Figure 1. Māte Mahādēvi.

Figure 2. Lingāyat followers worship the iștalinga.

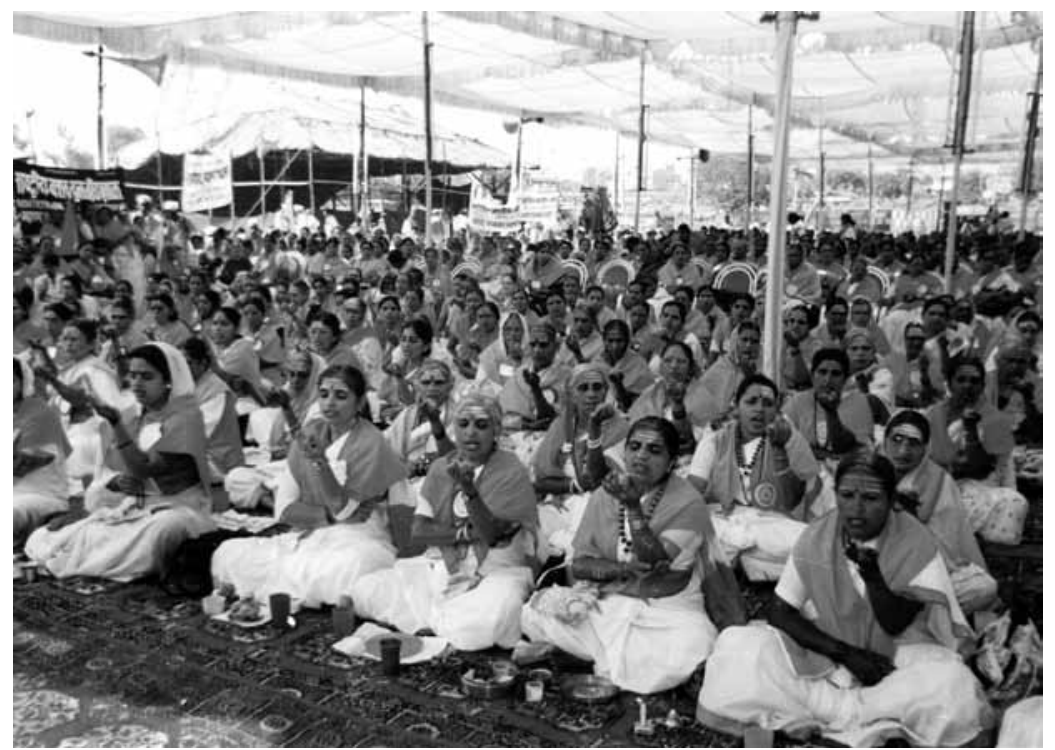

